\title{
COMMENT
}

\section{Other nature: geodiversity and geosystem services}

The concepts of biodiversity and ecosystem services have become widely established and adopted within and beyond nature conservation circles. But biotic nature is only part of nature. The existence and importance of abiotic nature often goes unrecognized and is certainly undervalued. This Comment tries to redress the balance by outlining some recent developments in valuing and conserving abiotic nature, particularly the important concepts of geodiversity and geosystem services.

The imbalance in nature conservation circles between biotic and abiotic nature is neatly illustrated by Milton's statement (2002, p. 115) that 'Diversity in nature is usually taken to mean diversity of living nature. . '. However, there are abiotic equivalents of biodiversity and ecosystem services, and any sensible approach to nature conservation and natural resource management needs to take account of both living and nonliving nature.

\section{Geodiversity}

Geodiversityhas been defined as 'the natural range (diversity) of geological (rocks, minerals, fossils), geomorphological (land form, processes) and soil features' (Gray 2004, p. 8) and is therefore the abiotic equivalent of biodiversity. The term was first used in 1993 (Sharples 1993; Wiedenbein 1993) following the international agreement on the Convention on Biodiversity at the Earth Summit in Rio de Janeiro in the previous year. As a result, it became obvious to many geoscientists that since the abiotic Earth also has a huge diversity, an appropriate title to encompass this would be geodiversity.

For example, up to 5000 named minerals have so far been discovered on Earth, some of which are extremely rare and could easily be lost. In turn, these minerals combine to create hundreds of named and classified rock types. Millions of fossil species have been described, with new discoveries being made every day. There are 19000 named soil types in the USA alone (Brady \& Weil 2002). In addition, there is a huge diversity of physical processes, physical landscape character and topographic detail. In fact, the Earth is the most geodiverse body known in the solar system, and indeed beyond it, and it may be no coincidence that it is also the place where complex life has developed (Ward \& Brownlee 2000).

Since the early 1990s, the concept of geodiversity has been adopted in many countries, initially in Tasmania, Australia (see for example Sharples 1993, 2002; Kiernan 1996; Dixon 1996; Eberhard 1997) and subsequently in Europe (see Johansson 2000; Nieto 2001; Brilha 2005) and other countries. In 2008, the IUCN (International Union for Conservation of Nature) adopted Resolution CGR4.MOT055 (see http:// intranet.iucn.org/webfiles/doc/IUCNPolicy/Resolutions / 2008_WCC_4/English/RES/res_4_040_conservation_of_ geodiversity_and_geological_heritage.pdf) relating to the conservation of geodiversity and geological heritage. In the UK, over 40 local geodiversity action plans (LGAPs) have been published or are in preparation and a national $U K$ Geodiversity Action Plan (UKGAP) was finalized in 2011 (see http://www.ukgap.org.uk). In Australia, the National Heritage Charter (Australian Heritage Commission 2002) gives equal weight to biodiversity and geodiversity.

Although some elements of geodiversity are stable, static or prolific, many are sensitive and vulnerable. Examples include fossil sites brutalized by commercial collectors using power tools, delicate speleothems in limestone caves snapped off by visitors, and natural topographies bulldozed to create golf courses. Threats to geodiversity include quarrying, land development, engineering of coasts and river channels, forestry, agriculture, recreation/tourism and overexploitation of fossil and mineral sites (Gray 2004).

These threats create a need for geoconservation, and geodiversity also constitutes an important basis for selecting geoconservation sites and has been adopted, albeit not always by that specific name, by several countries. For example, new national parks in the USA must not represent a feature already adequately represented in the national park system, and national natural landmarks must be considered the best examples of a type of biotic community or geologic feature. The aim is to recognize and protect representatives of the diversity of the USA's natural heritage, including geodiversity. Similarly, the UK has long accepted that one of the criteria for selecting geoconservation sites should be to protect a representative selection of the country's earth science features, events or processes (Ellis et al. 1996). It is also increasingly being used by UNESCO (United Nations Educational, Scientific and Cultural Organization) and the IUCN in assessing future earth science sites for inclusion in the World Heritage List (Dingwall et al. 2005; Warboys \& Winkler 2006; Williams 2008). Sharples (2002) clearly distinguished between:

(1) geodiversity: the quality considered worthy of conservation,

(2) geoconservation: the endeavour of conserving this geodiversity, and

(3) geoheritage: particular examples of geodiversity that may be specifically identified as having conservation significance. 


\section{Geosystem services}

A crucial concept that has been understood for many years, but has recently become central to nature conservation, is that of the ecosystem services approach. Ecosystem services are the goods and functions of ecosystems that benefit society. Their intangible values tend not be to be included in economic or policy decisions. Daily (1997, p. 3), in the foundation work on this topic, described ecosystem services as: 'the conditions and processes through which natural ecosystems, and the species that make them up, sustain and fulfil human life. They maintain biodiversity and the production of ecosystem goods, such as seafood, forage, timber, biomass fuels, natural fiber, and many pharmaceuticals, industrial products, and their precursors. In addition to the production of goods, ecosystem services are the actual life support functions, such as cleansing, recycling, and renewal, and they confer many intangible aesthetic and cultural benefits as well'.

Several environmental economists have subsequently attempted to value the world's ecosystem services and natural capital (for example Costanza et al. 1997; Balmford et al. 2002). More recently, the Millennium Ecosystem Assessment (2003) classified ecosystem services into provisioning, regulating, supporting and cultural services.

While definitions make it clear that an ecosystem includes the abiotic components of habitat, it is also clear that most published work on ecosystem services refer entirely or mainly to biotic services (see, for example, Daily's description above). But, just as geodiversity is the abiotic equivalent of biodiversity, so geosystem services can be recognized as the goods and functions associated with geodiversity (Gray 2008). There are over 25 distinctive geodiversity values that can be classified according to the Millennium Ecosystem Assessment (2003) with the addition of a 'knowledge' category (Fig. 1).

The wide range of geosystem services is the direct result of the planet's geodiversity, and many abiotic values of nature are not represented in the ecosystem services approach as currently promoted (Fig. 1). This is particularly true for most of the provisioning and knowledge services; knowledge of the history of the Earth is derived from geological research, including the analysis and interpretation of geological, palaeontological, geomorphological, geochemical, geophysical and other methods, alongside the development of dating techniques. There is a strong case for conserving the important international, national and local sites that either have allowed, or have the potential to allow, scientists to reconstruct Earth history and the evolution of life. In terms of provisioning, construction materials, industrial minerals and ornamental products are mainly derived from the physical Earth without the intervention of any significant role for wildlife. Society makes very extensive use of these physical materials for construction projects and the manufacture and use of items on which modern society depends, such as electronics, telecommunications, transport or energy, but it is also important that these materials are used sustainably. These and the other geosystem services deserve greater recognition by society because a modern sustainable society could not flourish and develop without them. In turn, it is the geodiversity of these resources and their brilliant utilization by humans that have allowed modern society to evolve.

Within the regulating, supporting and cultural categories there are also important roles for geodiversity. There are many geotourism sites that are unrelated to ecosystems or species, such as the Grand Canyon; it is certainly an ecosystem, but this is not the main reason for the hundreds of thousands of visitors it receives each year. They go to experience the physical immensity that is the Canyon; they stare into it, travel down into it, fly through it or camp within it. Another example is that it is mainly the diversity of physical environments (such as geomaterials, topography, hydrology or physical processes) that has allowed biodiversity to evolve. Geodiversity provides the platforms and the range of physical habitats in which wildlife can flourish, whether in chalk grasslands, salt marshes or mountain environments.

However, some functions normally referred to as ecosystem services (Daily 1997) are actually shared between biotic and abiotic systems. For example, mitigation of floods and droughts is partly accomplished by ecosystems, but also by natural physical materials (such as rainwater infiltration through sediment and rock or storage in groundwater aquifers) or structures (for example levees, beach barriers and sand dunes). Similarly generation and renewal of soil and soil fertility must be partly due to geosystem processes (for example weathering and soil profile development). Thus sustainable management of natural resources must involve both biotic and abiotic systems (Brilha 2002) and perhaps 'natural services' is a more inclusive term for the goods and functions attributable to all of nature. This terminology would help to create a more comprehensive and integrated approach, since many natural services involve both biotic and abiotic elements (Daily's 1997 book is entitled Nature's Services).

There are few studies targeting economic valuation of geosystem services. Most significant is the study by Webber et al. (2006), who undertook questionnaire valuation surveys, presenting hypothetical options for the future management of the Wren's Nest National Nature Reserve at Dudley in the English Midlands, a site with good exposures of fossiliferous Silurian limestones and shales in disused quarries and underground caverns. They also carried out an economic multiplier study to estimate the benefits of geodiversity to the economy of the Isle of Wight off the south coast of England, famous for its Mesozoic geology. Their conclusion was that geodiversity generates between GBf, 2.6 million and GBf 4.9 million to the economy of the Isle of Wight and supports 324-441 full-time equivalent local jobs.

\section{Conclusions}

The development of the concepts of biodiversity and ecosystem services has further reinforced the imbalance in 


\section{Regulating}

1. Atmospheric and oceanic processes (e.g. dynamic circulations, atmospheric chemistry, hydrological cycle).

2. Terrestrial processes (e.g. rock cycle, carbon cycle, geomorphological processes).

3. Flood control (e.g. infiltration, barrier islands, river levees, sand dunes).

4. Water quantity and quality (e.g freshwater storage in aquifers, lakes, reservoirs, glaciers, soil and rock as natural filters).
Provisioning

14. Food and drink (e.g. natural mineral water, salt, geophagy).

15. Nutrients and minerals for healthy growth.

16. Fuel (e.g. coal, oil, gas, uranium, geothermal and hydroelectric energy, wave and wind power).

17. Construction materials (e.g. stone, brick, sand, gravel, steel, cement, bitumen, slates, glass).

18. Industrial minerals (e.g. fertilizers, pharmaceuticals, metals, alloys).

19. Ornamental products (e.g. gemstones, precious and semiprecious metals).

20. Fossils.

\section{Supporting}

5. Soil processes (e.g. weathering, soil profile development) and soil as a growing medium.

6. Habitat provision (e.g. caves, cliffs, limestone pavements, salt marshes).

7. Land as a platform for human activity (e.g. building land).

8. Burial and storage (e.g. human and animal burial, municipal landfill, radioactive waste storage, oil \& gas reservoirs, carbon capture \& storage).

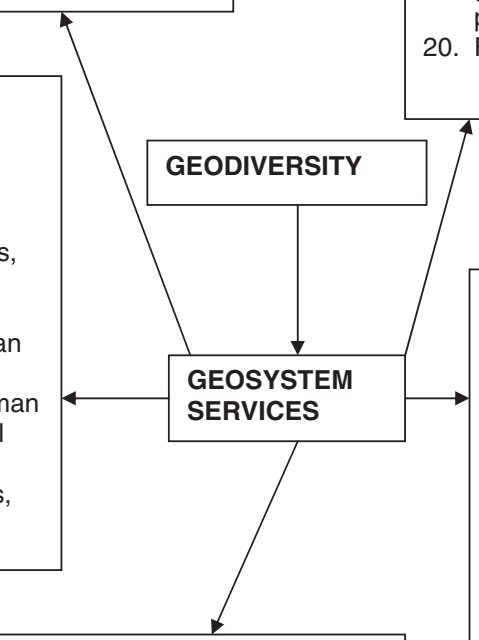

Cultural

9. Environmental quality (e.g. local landscape character, therapeutic landscapes).

10. Geotourism \& leisure (e.g. spectacular mountain views, rock climbing, fossil collecting).

11. Cultural, spiritual and historic meanings (e.g. folklore, sacred sites, sense of place).

12. Artistic inspiration (e.g. geology in sculpture, literature, music, poetry, painting).

13. Social development (e.g. local geological societies, field trips).

\section{Knowledge}

21. Earth history (e.g. evolution of life, extinction, origin of landforms, palaeoenvironments).

22. Understanding physical processes.

23. Geoforensics.

24. History of research (e.g. early identification of unconformities, fossils, igneous rocks)

25. Environmental monitoring and forecasting (e.g. baseline studies for pollution research, ice cores, sea-level change).

26. Education \& employment (e.g. sites for field trips and professional training, employment in geoparks).

Figure 1 The diversity of geosystem services. The layout is based on a scheme developed by De Groot (1992), adapted for geodiversity by Webber et al. (2006).

nature conservation between biotic and abiotic elements. Modern society depends on both ecosystem and geosystem services, and a balanced approach to natural resource management must include both biotic and abiotic factors.

\section{Acknowledgements}

I am grateful to Dr Colin Prosser and Dr Stewart Clarke, both of Natural England, and to three anonymous referees for their comments on earlier versions of this paper, but the views expressed here are my own.

\section{References}

Australian Heritage Commission (2002) Australian Natural Heritage Charter. Canberra, Australia: Australian Heritage Commission

Balmford, A., Bruner, A., Cooper, P., Costanza, R., Farber, S., Green, R.E., Jenkins, M., Jefferiss, P., Jessamy, V., Munro, K., Myers, N., Naeem, S., Paavola, J., Rayment, M., Rosendo, S., Roughgarden, J., Trumper, K. \& Turner, R.K. (2002) Economic reasons for conserving wild nature. Science 297: 950-953.

Brady, N.C. \& Weil, R.R. (2002) The Nature and Properties of Soil. Thirteenth edition. New Jersey, USA: Prentice Hall.

Brilha, J. (2002) Geoconservation and protected areas. Environmental Conservation 29: 273-276. 
Brilha, J. (2005) Patrimonio Geologico e Geoconservacao. Viseu, Portugal: Palimage Editores.

Costanza, R., d'Arge, R., de Groot, R., Faber, S., Gresso, M., Hannon, B., Limburg, K., Naeem, S., O’Neill, R.V., Paruelo, J., Raskin, R.G., Sutton, P. \& Van Den Belt, M. (1997) The value of the world's ecosystem services and natural capital. Nature 387 : 253-260.

Daily, G.C. (1997) Nature's Services: Societal Dependence on Natural Ecosystems. Washington, DC, USA: Island Press.

de Groot, R.S. (1992) Functions of Nature. Groningen, the Netherlands: Wolters-Noordhoff.

Dingwall, P., Weighell, T. \& Badman, T. (2005) Geological World Heritage: a Global Framemork. Gland, Switzerland: IUCN.

Dixon, G. (1996) Geoconservation: an international review and strategy for Tasmania. Occasional Paper 35, Parks and Wildlife Service, Tasmania, Australia.

Eberhard, R., ed. (1997) Pattern and Process: Tomards a Regional Approach to National State Assessment of Geodiversity Canberra, Australia: Australian Heritage Commission.

Ellis, N.V., Bowen, D.Q., Campbell, S., Knill, J., McKirdy, A.P., Prosser, C.D., Vincent, M.A. \& Wilson, R.C.L. (1996) An Introduction to the Geological Conservation Reviem. Peterborough, UK: Joint Nature Conservation Committee.

Gray, M. (2004) Geodiversity: Valuing and Conserving Abiotic Nature. Chichester, UK: Wiley.

Gray, M. (2008) Geodiversity: a new paradigm for valuing and conserving geoheritage. Geoscience Canada 35(2/3): 51-59.

Johansson, C.E., ed. (2000) Geodiversitet $i$ Nordisk Naturvaird. Copenhagen, Denmark: Nordisk Ministerråad.

Kiernan, K. (1996) The Conservation of Glacial Landforms. Hobart, Australia: Forest Practices Unit.

Millennium Ecosystem Assessment (2003) Ecosystems and Human Well-being: a Framemork for Assessment. Washington, DC, USA: Island Press.
Milton, K. (2002) Loving Nature: Tomards an Ecology of Emotion. London, UK: Routledge.

Nieto, L.M. (2001) Geodiversidad: propuesta de una definicion integradora. Boletin Geologico y Minero 112: 3-12.

Sharples, C. (1993) A Methodology for the Identification, of Significant Landforms and Geological Sites for Geoconservation Purposes. Tasmania, Australia: Forestry Commission.

Sharples, C. (2002) Concepts and principles of geoconservation. Tasmanian Parks \& Wildlife Service [www document]. URL http://www.dpiw.tas.gov.au/inter.nfs/Attachments/SJON57W3YM/\$FILE/geoconservation.pdf

Warboys, G.L. \& Winkler, C. (2006) Natural heritage. In: Managing Protected Areas: a Global Guide. ed. M. Lockwood, G.L. Worboys \& A. Kothari, pp. 3-40. London, UK: Earthscan.

Ward, P.D. \& Brownlee, D. (2000) Rare Earth: Why Complex Life is Uncommon in the Universe. New York, NY, USA: Copernicus Books.

Webber, M., Christie, M. \& Glasser, N. (2006) The social and economic value of the UK's geodiversity. Research Report 709, English Nature, Peterborough, UK.

Wiedenbein, F.W. (1993) Ein Geotopschutzkonzept für Deutschland. In: Geotopschutz Probleme: der Methodik und der Praktischen. Saarbrucken, Germany: University of Saarland.

Williams, P. (2008) World Heritage Caves and Karst: a thematic study. Gland, Switzerland: IUCN.

MURRAY GRAY*

School of Geography

Queen Mary University of London

Mile End Road, London E1 4NS, UK

* Correspondence: Dr Murray Gray e-mail: j.m.gray@qmul.ac.uk 